\title{
Implementation of Domestic Violence Act: A study with specific reference to the district of Chittorgarh
}

\author{
Rinku Gangwani \\ Research Scholar University College of Law Mohanlal Sukhadia University Udaipur (Raj.)
}

\section{Introduction}

Being the student of Master of Legal Laws and especially as I have completed my specialization of Criminal Law, Criminology and Forensic Science, I got attracted towards the topic of "Implementation of Domestic Violence Act: A study with specific reference to the district of Chittorgarh". Basically the reason of the attraction towards topic is the situation of violence against women in Chittorgarh district is so much far from our thoughts especially in 2008, 2009 and 2010. And after a short term court visit when I came to know that our legislations are being misused in courts and advocates are only working in money minded way, I have make up my mind to pen down on this area. We are living in a great nation where marriage is considered to be a sacrament institution and today women are being harassed everywhere even they are not safe in their houses. They have not any awareness of their rights nor are the advocates trying to solve the matters in a compromising way they don't hesitate even before breaking up the sacrament relation. Thus with this view I had started studies with special reference to Chittorgarh district.

In India, the problem of violence against women is the result of a long standing power imbalance between man and women. A number of laws have been enacted to improve a lot of women, but neither the constitution nor the laws have been successful in changing the status of women. We worship women as "Goddess", regard her as "Mother", love her as "Wife" and she is most affectionate to us as "Daughter" but still we commit violence against her. The concept of Ardhangini (half of the body) seems to be restricted only in literatures and have never implemented in practical life. One in the three women throughout the world will suffers this violence in her lifetime, she is beaten, raped, assaulted, trafficked, and harassed of forced to submit to harmful practices such as female genital mutilation. In a country like India, it is difficult to rely on statistics pertaining to domestic violence cases. The data shows that one crime against women in every three minutes, one case of abuse by family in every nine minutes, and at least 18 women are killed everyday for dowry in India. The data may show that such offences being committed may be going up or down. But in reality, women are afraid of even lodging FIRs or DIRs in police stations. The familiar argument is in our social set-up, the woman's only place is in her husband's house.

Before the Domestic Violence Act came into force laws for women which protect them form cruelty all the laws from Indian Penal Code sections 304-B and 498-A. but there still remain some lacunas in implementation of these provisions as their extension for cruelty is quite limited, only husband and relatives of husband. Time needs much more distillated form of law which protects the women from a daughter to daughterin-law, from educated women to uneducated women. Domestic violence is not only committed against daughter-in-law even it takes from the natal age or from girl child's birth.

So that "THE PROTECTION OF WOMEN FROM DOMESTIC VIOLENCE ACT, 2005" came into force to patch up all the issues in old laws.

\section{Meaning}

\section{Domestic Violence}

"Domestic" means within the realm or the territory of house and violence means action using physical force and intended to hurt or kill someone to cause damage. As the meaning by oxford, separately suggest the criteria of the world. Thus the term Domestic Violence means an action or physical force which is being used within the realm of territory of house to intend to hurt or cause damage any particular subject in the domestic household.

\section{Definition}

Section 3 of "The Protection of Women from Domestic Violence Act, 2005"

Any act or any omission of the respondent shall constitute "Domestic Violence" in case:

1. Harms or injures or endangers the health, safety, life, limb or well-being, whether mental or physical, of the aggrieved person or tends to do so and includes causing physical abuse, sexual abuse, verbal and emotional abuse and economic abuse; or 
2. Harasses, harms, injures or endangers the aggrieved person with a view to coerce her or any other person related to her to meet any unlawful demand for any dowry or other property or valuable security; or

3. Has the effect of threatening the aggrieved person or any person related to her by any conduct mentioned in clause (a) or clause (b); or

4. Otherwise injures or causes harm, whether physical or mental, to the aggrieved person.

\section{Domestic Violence against women with special reference to Chittorgarh}

Domestic violence, so alien to our image of non-violence and respect for women hood is emerging as one of the least recognized and most appalling crimes. The law of evidence does not recognize the basic fact that wives and daughters suffer from a special kind of violence of which only they are the victims, it occurs within the four walls of the house and cannot be easily proved because of the nature of the crime and the overwhelming social compulsions.

Domestic violence is the most prevalent yet the least reported crime in the society. Battered women are reluctant to report that they have beaten up. It is their feeling of guilt and shame that prevents them from discussing the issue and loyalty toward their husband prevents them from reporting the crime. They also fear that the husband will get annoyed and desert the, or they will lose the economic support of their husbands or else such complaints will harm their careers.

Hundreds of women are battered or even tortured and killed within the realm of their homes but they go on living in traumatic situations and they have accepted "acha ho ya bura, hamara pati hai.." ( Even good or bad, he is still our husband) A large number of victims have shunted between their natal home and matrimonial home several times before finally becoming a victim of death. Women are emotionally vulnerable and physically weak; they lack the legal right to live in the house where they have lived with the husband for years, after their husband deserts or divorce them.

\section{Alarming dimensions of the Crime in Chittorgarh}

Offences of Domestic violence generally reported to Chittorgarh police are as follows:-

1. Cruelty

2. Rape/ Sexual harassment at home

3. Dowry deaths

\section{Cruelty}

Cruelty extends to mental cruelty, mental cruelty, physical cruelty and sexual cruelty. In new dimensions of cruelty it takes a vast area to cover. Stray incidents of violence do not the spouse affect her health, then this can be said to constitute legal cruelty.

Rights also require some attention that not to picking a phone call by wife is also consider as cruelty. Section 498-A of Indian Penal Code was enacted to deal with cruelty. Wife beaters are not the uncommon monsters; they are ordinary men who have learnt the male role and male behavior from their father and their society. They are only carrying forward their tradition. No one, not even the neighbor's friends or other people who know or have seen the wife being beaten, are prepared to give evidence against the husband. It is not easy task to get a case registered under section 498-A IPC. The patriarchal structure of the society approves of many indignities that are heaped on the wife and this is the reason why it is so difficult to prove cases of wife beating. The violence can range from slaps and kicks to broken bones, torture and attempted murder and even murder itself. There are about 116 cases of cruelty reported in a "Mahila Police Thana (Women police station) by which only 29 are decided finally. There are about 700 reported cases of 498-A, IPC in Chittorgarh in 2010. It is seen that utmost cruelty cases are reported in rural areas of Chittorgarh rather than urban. For instance, villages like Dungla (46 cases), Nimbahera (118 cases), Bari sadri (71 cases) and kapasan (58 cases) are overloaded from domestic violence cases. This is only a reported graph under police, despite of this there are many more cases hidden behind the curtain almost every family. A women's life is worth a banana in Chittorgarh whether in role of mother, daughter, daughter-in-law or mother-in-law.

\section{Misuse of Section 498 A}

$>\quad$ One of the negative forces that have adversely impacted Indian families in recent years is the legislation which was added by amendment in 1983, section 498 A of the Indian Penal Code- "Cruelty by husband or relatives of husband". Though it was introduced with good intentions, but due to bad planning and execution it has become a handy tool of "Legal Terrorism".

This Section enables a wife to get her in laws arrested without injury. Unethical and immoral women and their greedy families use it to harass the husband's family and extort money from them. 
Given the corrupt and lawless way of police, this provision came to be misused and abused widely by the police to extract bribes as well as by unscrupulous women and their lawyers to blackmail groom's family even on trumped up charges.

It is not just men but even a lot of women, who have suffered the consequences of irresponsible use of section 498A, believed that it is extremely one sided and an "Instrument of Blackmail" rather than of securing justice.

$>\quad$ On the other hand many genuine victims of violence hesitate to seek legal redress under 498A because it would mean getting their husbands and in-laws sent behind bars.

$>\quad$ In many cases women wanted a divorce because of having an extra-marital affair. These type of immoral women do anything to get divorce whether they charged cruelty or they could prove impotency of husband.

$>\quad$ This law has been considered as a money making agenda in courts, so the advocates try to "Break the Families" by hook or by crook to get a large amount of money. Even advocates made any cock and bull stories for their client and gave them an imaginary sheet of questions and answers (generally asked by judge in the court) to memorize.

\section{Rape:-}

It includes marital rape and date rape as well. Violence against women within the family has become a contemporary issue in Chittorgarh. The physical and sexual abuse of women in public domain has become widely recognized. Laws have been change, shelter and treatment programs have been launched, and the documentaries have been made on the issue, yet sexual relations within married couple are less discussed and scantly research issues in India. Though widespread, sexual violence or marital rape is still regarded as tabooed issue.

Though marital rape is the most common and repugnant form of masochism in Chittorgarh society, it is hidden behind the iron curtain of marriage. Rape is rape, be it stranger rape, date rape or marital rape. Women themselves don't make a noise about it or talk about their experiences. This is because cultures worldwide discourage the women from openly discussing sexual matters, let alone within marriage.

\section{Dowry Death:-}

Dowry death is killing of a woman, ostensibly for not bringing sufficient dowry to the marriage. Rather than supporting women, the Dowry Prohibitions Act (1961) was passed as a measure to facilitate the implementation to the traditional ideal of marriage for all women. In Section 2 of The Dowry Prohibition Act, 1961 dowry includes any property or valuable security given or agreed to be given either directly or indirectly: By one party to a marriage to the other party to the marriage; or

By the parents of either party to a marriage or by any other person, to either party to the marriage or to any other person at or before or any time after the marriage in connection with the marriage of the said parties.

Apart from this Section 304-B of Indian Penal Code, 1860 \& Section 113 B of Indian Evidence Act, 1872 also provides definition of Dowry.

In Sindhi's there is a "specific demand" system of dowry which is known as "Boli" in regional language. In which groom's parents ask freely to bride's parents about cash \& gifts. These gifts given on special occasions and bride can be criticized and mistreated by their in-laws for not continuously providing dowry. These disputes can then escalate into wife beating, mental torture and finally murder-freeing the husband to remarry for a more lucrative dowry.

Richa murder case is still fresh in our mind, in which she was married to Udaipur and within fifteen days she is murdered heinously by her mother-in-law with the collusion of her husband. Her mother-in-law cuts her body in the pieces with a butcher knife. Chittorgarh and Udaipur both were closed in the condolence.

An another case of Harshita Kanwar, a victim of dowry harassment is reported in Jaipur, Harshita wanted to meet Ashok Gehlot (former chief minister of Rajasthan) and make a representation against police not acting on the harassment complaint against her husband and in-laws. Her in-laws were demanding 20lakhs and even divorce from her. Harshita, who was made to leave her husband's house in Ahmadabad, filed a complaint against them at the Gandhi Nagar women's police station on 24 March 2011.

\section{Conclusion:}

Dowry death is a crime which even not reported to the police because it defames the family's respect and honor. Bride burning cases are manifests in both rural and urban areas but least reported crime graph is only in rural area. Mostly cases of bride burning are reported in Akola, Begun, Mangalwad, and Shambhupura (Villages of Chittorgarh) rather than Chittorgarh district. Few killers in bride burning cases are arrested, fewer are prosecuted, and fewest finally sentenced. This is the actual scene of Chittorgarh crime. 
A study by primary collected data reveals that less education a women has, there is more likelihood of her approving and supporting violence. And some other studies done by telephonic interviews contradict findings and finally it reveals that couples with the lowest educational levels are less prone to violence than those who had attained higher education. The women with low education designate their complete dependency because with low educational background they will not be able to have economic independence, and their dependency would be one more cause to make them victim. A popular proverb is very fit here "History repeats itself". We should not forget that we are living in a town where Meera Bai and Rani Padmini had also suffered violence. Their history is also very heart-melting. Hence it is said for Chittorgarh that "it is a place which is unsafe for daughters and daughter-in-laws". Acts are always misused here, women are also tortured here whether educated or uneducated.

\section{References}

[1]. Crime against women \& Child: An emerging social problem, by Adesh.K.Devgan

[2]. Domestic Violence \& the Law. HRLN, Human Rights Law Network, India

[3]. The Protection of Women from Domestic Violence Act, 2005

[4]. Social Problems in India, Ram Ahuja

[5]. Crime against Women \& Protective Laws- Shobha Saxena

[6]. Domestic Information Report (DIR), Session Court, Chittorgarh

[7]. Crime data application under RTI Act, Serial No. 2247

[8]. Crime data (1.1.2010 to 31.12.2010) Rajasthan Police, Chittorgarh

[9]. Times of India, Jaipur/Friday, April 22, 2011

[10]. Dainik Bhaskar, Jaipur 27/3/2011

[11]. National Crime Records Bureau Nov 12, 2006

[12]. Combat Law-Vol 1, Issue 2-3, May-Aug 2010

[13]. Domestic Violence in marriage: in the light of theories of feminist jurisprudence

[14]. http://www.legalserviceindia.com/article/1263-Domestic-violence-in-marriage.html

[15]. Domestic Violence http://www.domesticviolence.in/

[16]. Sexual abuse (http://education.qldgov.av/)

[17]. http://Actsmartbesafe/violence/sexual.html 